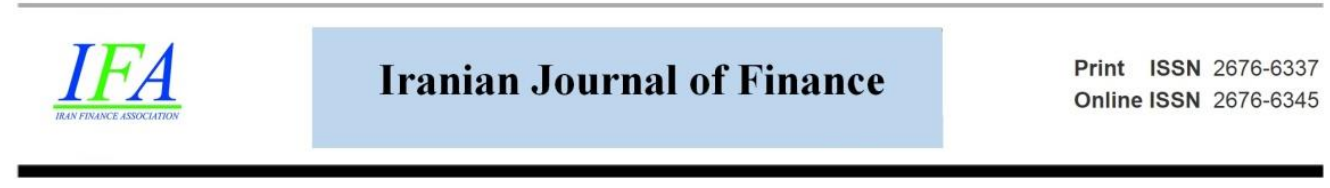

\title{
Investigating the Effects of Disclosure of Non-Financial Intangible Information on Investors' Judgment about Future Financial Performance of the Company
}

\section{Tahereh Mosallanezhad}

Ph.D. Candidate, Department of Accounting, Yasooj Branch, Islamic Azad University ,Yasooj,Iran (Email: T.mosalla214@yahoo.com)

\section{Shokrallah Khajavi*}

*Corresponding Author, Prof., Department of Accounting, Shiraz University, Shiraz, Iran. (Email: ShKhajavi@ rose.shirazu.ac.ir)

\section{Abdolkhalegh Gholami}

MA, Department of Auditing, Faculty of Management and Accounting, Allameh Tabataba'i University, Tehran, Iran. (Email: Gh.khalegh@yahoo.com)

\section{Hashem Valipour}

Associate Prof., Department of Accounting, Firozabad Branch, Islamic Azad University, Firozabad, Iran. (Email: H.valipour@gmail.com)

Document Type: Original Article Received: 2020/07/23
2021, Vol. 5, No. 2. 21-45

Published: 2021/04/21

\begin{abstract}
The present study aims to investigate the needs of users in connection with the information of intangible assets in current financial statements with an emphasis on the way of disclosing non-financial information. For this purpose, the effect of the two independent variables of causal links' discussion and level of non-financial performance on the financial performance of the firm, as the dependent variable, has been studied. The research is applied in terms of its objective and it is a survey in terms of the research design. The research population includes $\mathrm{PhD}$ students of accounting in top-ranking universities of Iran. Statistical methods, including test ratio, single-sample t-test, independent t-test, and one-way and two-way variance analysis have been used to test hypotheses. The findings show that the disclosure of non-financial intangible information along with causal links does not affect the judgment of investors
\end{abstract}


with a low or high level of knowledge. However, it should be noted that the recall of the performance in terms of non-financial criteria by investors, who have a causal link discussion, is higher than others.

Keywords: Fair Value, Performance Prediction, Quality, International Financial Reporting Standards, Small and Medium-sized Entities.

DOI: 10.30699/IJF.2021.240783.1144

Publisher: Iran Finance Association

Copyright: author(s)

Type of License: Creative Commons License (CC-BY 4.0)

\section{Introduction}

Since the late twentieth century, interest in intangible assets and their impact on market value has encouraged companies to increase investment in human resources, research and development, new technologies and so on (Buzinskiene, 2017). Intangible assets are one of the most important issues and according to Swanson (2018), intangible assets have become one of the most important drivers of corporate value in recent years (Parvaee and Kordestani, 2018). However, the current accounting system does not meet the information needs of the knowledge age and is unable to properly measure and disclose intangible assets. According to current accounting standards, the business unit records most of its intangible investments in the expense account or depreciate them voluntarily (Arefmanesh and Rahmani, 2015).

Decision-makers usually make decisions based on corporate financial information. Despite this, there are claims about the fact that financial statements do not provide comprehensive and complete information to users without including non-financial performance (Eccles et al., 2001; Dnial et al., 2011; Bini et al., 2018). Stakeholders of companies, such as investors and customers, are increasingly looking for non-financial information to make decisions (Yari, 2018).

Many researchers have attempted to study the effect of disclosure of intangible information, especially non-financial information. Some researchers (such as Lev, 2001; Eccles, Herz, Keegan, Phillips, 2001; and Financial Accounting Standards Board, 2002) rely on the assumption that investors react to greater disclosure of intangible information. Sometimes, simple disclosure of non-financial intangible information makes investors consider this information in their judgments. On the other hand, the relationship between today's intangible activities and non-financial criteria and future financial results is very complex. If these relationships are ignored or misinterpreted, 
even more disclosure of non-financial intangible information may not affect investors' judgment (Yen, 2004).

At present, there are few studies on intangible assets in Iran and most related studies have considered the measurement of these assets (such as Arefmanesh and Rahmani, 2015; Mashayekhi et al., 2014). However, due to the complex relationships between intangible information, especially nonfinancial intangible criteria and future financial performance, the measurement and disclosure of intangible assets alone may not be enough to influence investors' judgment. In order to alleviate some of these problems, there is a need to focus more on non-financial information in company disclosures. It is assumed that providing complementary information in the form of causal links' models about non-financial criteria and their relationship with future financial performance criteria (as a decision-making facilitator tool) helps investors make decisions. The amount of investor knowledge about the industry affects the use of non-financial intangible information in performance evaluation.

Therefore, this study attempts to examine the method of disclosure of non-financial intangible information and its impact on investor's judgment and provide evidence about the role of disclosure of complementary causal links and the level of investors' knowledge about the industry in the use of nonfinancial information. Due to the effect of the level of knowledge about the industry on the use of non-financial criteria, studies have been conducted separately regarding the high knowledge and low knowledge of investors about the industry.

\section{Theoretical foundation}

With the beginning of the first evidence regarding the value of intangible resources, special attention to "Research and Development" (R\&D) activities (Lev, 1999) caused researchers to focus on the nature of this published information (Mehrpoyafar, 2016). Companies invest in $R \& D$ to innovate. Intangible assets arising as a result of $R \& D$ activities face many problems. According to the statement of the financial accounting standards board (2001), all R\&D expenditures, except for software development costs, are recorded in the expense account at the time of occurrence (Mazaheri, 2014).

Pharmaceutical companies are among the companies that usually invest heavily in $R \& D$ activities to increase value and competitiveness in the market. In pharmaceutical companies, the amount of investment in R\&D activities has a positive effect on future financial performance (through product sales 
revenue). This effect is a function of the amount invested, the success of the product development, the success in obtaining the approval of the Food and Drug Administration (FDA), and the speed of completion of the new products on the production line. Therefore, in the present study, non-financial criteria, such as the number of projects in the development line, the approvals of the food and drug administration, and the time of completion of the new product have been considered as non-financial intangible criteria.

According to the "Functional Fixation" theory, people use signs and symbols to judge the future. It is as if these signs and symbols have fixed concepts and meanings over time and are always relevant to the subject under judgment, without regard to the way in which these symbols are calculated, as well as the change in the subject matter of which these symbols represent (Hendricksen, 1982). A pharmaceutical company with high R\&D activities may report a significant increase in revenue, but due to higher R\&D costs, it reports a smaller increase in profit. In fact, increase in $R \& D$ costs can reduce net profit (Valizadeh larijani and Hadidifard, 2016). With this scenario, how does an investor predict future financial performance? First, profit forecasting is difficult because of uncertainty in the stability of $R \& D$ costs. In addition, although revenue forecasting is simpler than profit and revenue is not directly affected by current $R \& D$ costs, revenue timing is significantly affected by $R \& D$ activities. Also, disclosure of $R \& D$ costs is the input of the process, not the output. For example, two companies with the same R\&D costs have different financial prospects because of the different relative returns on $R \& D$ investment. As a result, disclosure of $R \& D$ costs alone cannot help investors differentiate between the two companies (Yen, 2004).

Based on the theory of "Anchoring", when making a decision, people first select a figure from among the available information as an anchor and then try to adjust this figure according to other information. The problem is that not everyone can completely make the adjustments once they fund the anchor (Hendricksen, 1982). Lev (2001) and Eccles et al. (2001) worked on companies that provided more non-financial intangible information about innovation activity. They argue that disclosure of non-financial criteria provides more information about companies' performance than disclosure of R\&D costs alone (Yen, 2004). In this research, it is expected that providing non-financial intangible information to the investor will reduce the error of anchoring.

Recent research in psychology suggests that information that is causally linked to the judgment variable is given more attention (Einhorn and Hogarth, 1986; Tversky and Kahneman, 1980; and Ajzen, 1977). These researchers 
argue that more attention is because people tend to organize events in terms of cause-and-effect relations.

Upton (2001) stated that "many non-financial criteria are unknown to users of business information." It seems that a developed causal model that shows the cause and effect links between non-financial intangible criteria and future financial performance can help investors in processing non-financial information and provide a framework for using non-financial intangible information in their judgment. In the present study, along with a questionnaire, a graphic table that hypothetically shows the causal links between nonfinancial criteria and financial performance of the company has been provided to some participants.

Due to the complex relationship between non-financial criteria and future financial results, non-financial intangible information may not be taken into account in investors' judgment of future financial performance. Investors with knowledge of the industry are less prone to this complexity because they are familiar with non-financial criteria that are the input to the investment decision process. They are also more likely to have a causal model (Yen, 2004). Therefore, investors with a high level of knowledge about the industry are expected to receive non-financial information and use it to judge future performance, even if the discussion of complementary causal links is not provided. However, disclosure of non-financial information alone may not affect the judgement of investors with little knowledge about the industry.

\section{Research Background}

Sharma and Kaur (2019) carried out a study entitled "intangible assets: reporting and hidden value criteria" to investigate the reporting of intangible assets in Indian companies during 2010-2016. They examined the difference between book value and market value through content analysis of financial statements and hidden value measure. Findings indicated different results in reporting intangible assets because there was a steady increase in the level of disclosure of intangible assets from 2010 to 2015, while there was less disclosure by companies in 2016. This research proposes that accounting regulators should establish uniform criteria for the classification and reporting of intangible assets. Companies should also pay more attention to the reporting of intangible assets.

Bini et al. (2018) conducted research entitled "the business model and disclosure of key non-financial performance measures" and proposed a 
business model as a tool for the transfer of corporate information with the aim of more useful disclosure of non-financial performance criteria. This model first introduced key non-financial measures in line with the strategic objectives of the company. Besides, it provided a comprehensive framework that shows how different resources combine to create corporate value. The results of their research contribute to the reliability of disclosure of information and provide insights for standard developers, legislators, consultants, and auditors seeking to develop guidelines for disclosure of non-financial information.

In a research study entitled "reliability of non-financial information: securing trust," Yari (2018) indicated that enterprises are increasingly reporting non-financial information throughout the world. Stakeholders, such as investors and customers, increasingly seek such information for making decisions. Also, those interested in reporting tend to know if they can trust this information. This confidence can be provided by an independent component. In large European corporations, a third party has been employed to ensure this confidence.

In addition to examining the value of financial information for registered intangible assets, Buzinskiene (2017) examined the value of non-financial information for non-registered intangible assets in Lithuanian companies. In this study, he revealed the true value of intangible assets available to Lithuanian companies. The research results confirmed this method of valuing intangible assets, which allows companies to calculate the fair value of an intangible asset. This extended information of intangible asset valuation is valuable for both corporate owners and investors. So that this value plays an important empirical role in assessing the impact of intangible assets on the market value of companies.

Ghanbari et al. (2017) examined the role of non-financial performance criteria in financial reporting. The results of the research showed that the nonfinancial performance criteria have a value relevance and reliability less than financial measures. Moreover, the intention and thinking of management and accounting rules and standards affect the methods of information disclosure.

Dyczkowska (2016) studied the determinants and quality of R\&D disclosure in the annual report of biotechnology companies in Poland. He examined the correlation between R\&D disclosure and financial and nonfinancial measures. In addition, he analyzed the statistical differences between companies with different levels of disclosure. Findings indicated that the majority of companies under study report limited R\&D information, or do not provide any R\&D disclosures; In addition, companies with higher liquidity and 
a higher market-to-book value ratio are more inclined to disclose $R \& D$ information.

Mahmudi et al. (2015) conducted a study entitled "the effect of the quality of voluntary disclosure of financial and non-financial performance measures." They identified the factors affecting performance evaluation (financial and non-financial criteria) and investigated the effect of their disclosure on the accuracy of profit prediction. The results indicated that there is a significant relationship between disclosure of effective performance evaluation criteria and accuracy of profit prediction. There is also a significant relationship between disclosure of non-financial performance evaluation measures and accuracy of profit prediction.

khani et al. (2014) studied the relationship between R\&D costs and stock returns of pharmaceutical companies accepted in the Tehran Stock Exchange from 2003 to 2011 . The results of the study showed that there is no significant relationship between R\&D costs and stock returns. This is because Iran's stock market is among the emerging markets and the lack of investors' awareness of $R \& D$ costs has caused R\&D costs not to affect stock returns. However, this is not the case in developed markets.

Arvidsson (2011) carried out a research study entitled "disclosure of nonfinancial information in annual report" and analyzed the management team's perspectives on different aspects of disclosure of non-financial information in the annual report. The results showed that voluntary disclosure compensates for the deficiency of financial statements for proper disclosure of intangible assets.

Yen (2004) investigated the effect of disclosure of non-financial intangible information on investors' judgment. The results indicated that comprehensive disclosure of non-financial information along with intangible asset information affects investors' judgment.

\section{Research questions}

1. Is disclosure of non-financial intangible information alone included in the performance judgment of investors with low knowledge of the industry? Will these investors differentiate between companies with above-average non-financial performance, below-average non-financial performance, and non-disclosing companies (control/baseline condition)?

2. Is disclosure of non-financial intangible information alone included in the performance judgment of investors with high knowledge of the industry? 
Will these investors differentiate between companies with above-average non-financial performance, below-average non-financial performance, and non-disclosing companies (control/baseline condition)?

3. How much does the discussion of complementary causal links provided with non-financial intangible information affect performance judgment by investors with low knowledge of the industry?

4. How much does the discussion of complementary causal links provided with non-financial intangible information affect performance judgment by investors with high knowledge of the industry?

5. Is recall of performance on non-financial criteria higher for investors who receive the causal links' discussion than other investors?

\section{Research hypotheses}

\section{* Primary hypotheses related to causal links}

H1: If non-financial intangible information is disclosed alone, it will not be included in the performance judgment by investors with low knowledge of the industry. These investors will not differentiate between companies with aboveaverage non-financial performance, below-average non-financial performance, and non-disclosing companies (control/baseline condition).

H2: If non-financial intangible information is disclosed alone, it is included in the performance judgment by investors with high knowledge of the industry. These investors will differentiate between companies with above-average nonfinancial performance, below-average non-financial performance, and nondisclosing companies (control/baseline condition).

H3: If the discussion of complementary causal links is provided with nonfinancial intangible information, performance judgment by investors with low knowledge of the industry will be more affected.

H4: If the discussion of complementary causal links is provided with nonfinancial intangible information, performance judgment by investors with high knowledge of the industry will not be affected.

\section{* Hypothesis related to the processing of non-financial information}

H5: Recall of performance on non-financial criteria will be higher for investors who receive the discussion of the causal links than other investors. 


\section{Research Method}

The present study is applied in terms of its objective, the research method is descriptive-analytical, and it is a survey in terms of the research design. The survey tool is a questionnaire. The statistical population of the study consists of $\mathrm{PhD}$ students of accounting in top-ranking universities of Iran. The reason for choosing $\mathrm{PhD}$ students of accounting, in addition to their homogeneity, is their awareness of the importance of intangible information in decision-making. Elliot et al. (2007) argue that such a statistical population is a valid alternative to investors. Previous studies (such as Hales et al., 2011; Winchel, 2008; Cardinal, 2008; Heitger, 2007; and Rahnama Rodposhti, 2012) have also used this statistical population, stating that such a statistical population has a relatively higher level of perception of the business, accounting, and evaluation and investment matters. Therefore, the results will be of high validity. Due to the small size of the study population, the majority of the population is selected as the statistical sample. The questionnaire was sent to more than 90 people and 50 questionnaires were returned. The average work experience of the study participants is more than 15 years. In addition, 36 participants (70 percent) had real investment experience in ordinary shares of companies and 39 participants (78 percent) decided to invest in ordinary shares of companies. After selecting the sample, participants were asked to play the role of the appraiser of ordinary shares of a hypothetical company and aim to add ordinary shares of the company to their investment portfolio. The hypothetical company was a profitable pharmaceutical company whose profit growth rate is very low relative to its revenue growth percentage. Participants were given information, such as company background and press releases, including financial and nonfinancial information about the company, along with the questionnaire. Participants were divided into three groups and different information was provided to each group. Then, one-sample t-test, independent t-test, one-way and two-way ANOVA were used to test the hypotheses.

\section{Research variables and conceptual model}

To model, the effect of disclosure of non-financial intangible information on investors' judgment about the future financial performance of the company, the effect of two independent variables of complementary causal links discussion and the level of non-financial performance on firm's financial performance, as a dependent variable, has been studied. In this regard, revenue (short-term decision criteria) and revenue growth (long-term decision criteria) were considered as representative of the company's financial performance criteria. 
Since the accounting rules related to $R \& D$ costs and its discretionary nature were expected to lead to increased impairment in profit judgements and profit growth, instead of profit and profit growth, the focus is on income and income growth. Based on the research hypotheses, a 2 X 2 plus 1 model has been used for research design. Independent variables in each category are manipulated. The first factor that is manipulated is complementary causal links' discussion. It is such that participants, who receive a report on non-financial criteria, receive it either with or without a complementary discussion of causal links between a firm's non-financial intangibles criteria and future financial performance. The second manipulated factor is the level of non-financial performance. The level of performance of the disclosing company is considered high or low in terms of non-financial criteria. The "plus 1 " is a control condition, in which participants receive neither the report on nonfinancial criteria nor the causal links' discussion. Therefore, the relationships between independent and dependent variables are tested in three conditions: control (disclosure of non-financial criteria is not done), no links (disclosure of non-financial criteria without additional causal link information), and with links (disclosure of non-financial criteria with complementary causal links' information). For the no links and with links conditions, the disclosure of nonfinancial measures shows the average high performance (HI NFM) and the average low performance (LO NFM). Figure 1 shows the conceptual model of the research design.

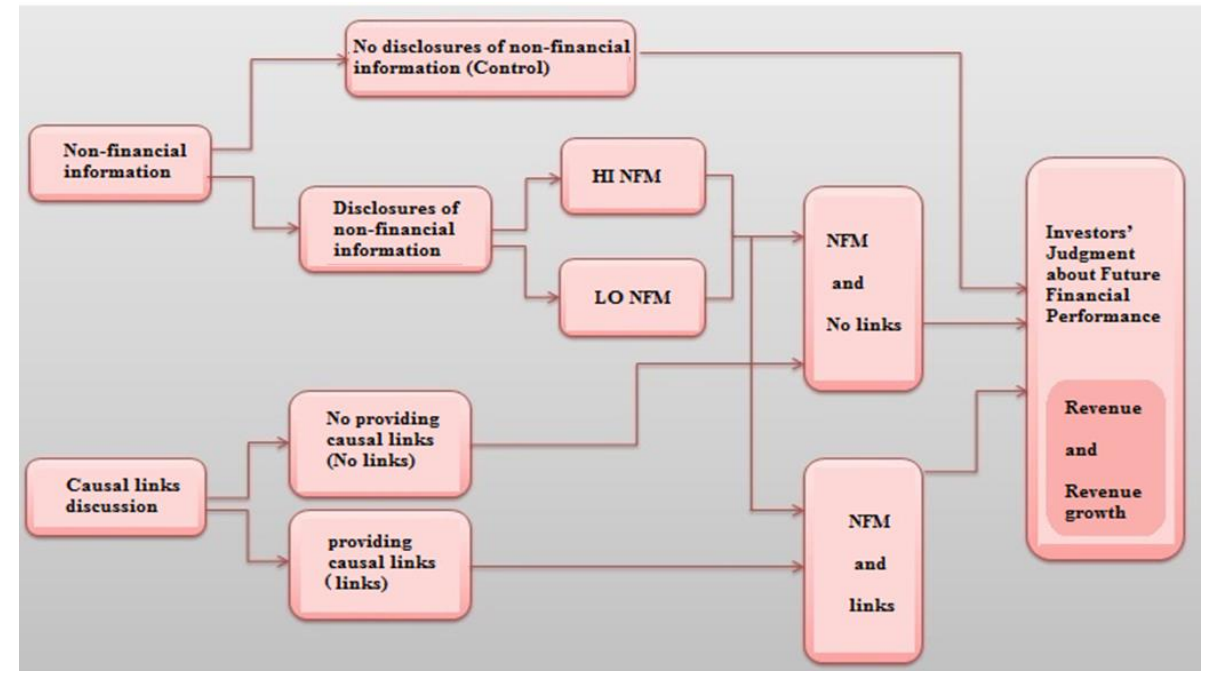

Figure 1. Conceptual Model (Researcher-developed) 
An open-ended question was used to measure next year's revenue (no response scale was used) and a 15-point Likert scale was used to measure revenue growth (next 3 to 5 years).

The first independent variable is the causal links (LINK). Participants who receive causal links' discussion can rank the usefulness of this variable in revenue judgment. They measure causal links' discussion a 15-point Likert Scale.

The second independent variable is the level of non-financial measures (NFM). The non-financial performance in this study is the competence of management and the quality of management work in the task of managing the company. A 15-point Likert Scale was used to measure this variable. In general, the firm's performance in terms of non-financial measures is classified into two levels of average high performance (HI NFM) and average low performance (LO NFM).

According to the role of knowledge about the industry in the use of nonfinancial measures, the sample is divided into participants with high knowledge and participants with low knowledge that are analyzed separately. In demographic questions, participants were asked to rate their knowledge of the industry (in this study, the pharmaceutical industry) on a 7-point scale (ranging from $1=$ no knowledge and $7=$ very high knowledge). Participants who rate themselves or lower are classified as participants with "low knowledge" and participants who rate themselves 5 or higher are classified as participants with "high knowledge".

\section{Research findings}

\section{First hypothesis testing}

Table 1 provides descriptive information about the dependent variables in the three groups in the position of providing non-financial information alone and low level of knowledge. 
Iranian Journal of Finance, 2021, Vol. 5, No. 2 (Mosallanezhad, T.)

Table 1. Descriptive statistic (non-financial information alone and low knowledge)

\begin{tabular}{|c|c|c|c|c|}
\hline Variable & Group & Mean & Standard deviation & N \\
\hline \multirow{3}{*}{$\begin{array}{c}\text { Next year } \\
\text { revenue }\end{array}$} & Control & 783310.40 & 226465.49 & 10 \\
\cline { 2 - 5 } & LO NFM & 776661.17 & 131280.58 & 6 \\
\cline { 2 - 5 } & HI NFM & 838943.83 & 136932.68 & 6 \\
\cline { 2 - 5 } & Total & 796669.73 & 176798.87 & 22 \\
\hline \multirow{3}{*}{ Revenue growth } & Control & 10.30 & 2.21 & 10 \\
\cline { 2 - 5 } & LO NFM & 9.33 & 2.73 & 6 \\
\cline { 2 - 5 } & HI NFM & 11.00 & 2.10 & 6 \\
\cline { 2 - 5 } & Total & 10.23 & 2.31 & 22 \\
\hline
\end{tabular}

Descriptive data in Table 1 show that there is not much difference between the groups in the average revenue forecast for the next year and the average assessment of revenue growth for the next 3 to 5 years.

The results of the first hypothesis testing for the three groups by one-way analysis of variance are presented below:

Based on the results obtained from Table 2, the next year's revenue forecast and the revenue growth forecast for the next 3 to 5 years were estimated to be the same in the three groups at the nominal level of 5 percent. These investors do not differentiate between companies with high performance, low performance, companies that do not provide non-financial information.

Table 2. One-way ANOVA to compare groups (providing non-financial information alone and low knowledge)

\begin{tabular}{|c|c|c|c|c|c|c|}
\hline Variable & source variable & $\begin{array}{l}\text { Sum of } \\
\text { squares }\end{array}$ & d.f. & $\begin{array}{l}\text { Mean of } \\
\text { squares }\end{array}$ & $\begin{array}{c}\mathbf{F} \\
\text { statistic }\end{array}$ & Sig. \\
\hline \multirow{2}{*}{$\begin{array}{l}\text { Next year } \\
\text { revenue }\end{array}$} & Intergroup & 14909371496 & 2 & 7454685748 & \multirow{2}{*}{0.22} & \multirow{2}{*}{0.804} \\
\hline & Intragroup & 641505296141 & 19 & 33763436639 & & \\
\hline \multirow{2}{*}{$\begin{array}{l}\text { Revenue } \\
\text { growth }\end{array}$} & Intergroup & 8.43 & 2 & 4.21 & \multirow{2}{*}{0.77} & \multirow{2}{*}{0.475} \\
\hline & Intragroup & 103.43 & 19 & 5.44 & & \\
\hline
\end{tabular}

Table 3 shows the results of the contrast test to compare the groups in pairs. As can be observed, all significance values are greater than 0.05; therefore, there is no significant difference between the groups in pair in predicting the next year revenue and revenue growth in the next 3 to 5 years. 
Table 3. Contrasts test (non-financial information alone and low knowledge)

\begin{tabular}{|c|c|c|c|c|}
\hline Variable & Contrasts & Value of contrasts & T statistic & Sig. \\
\hline \multirow{2}{*}{$\begin{array}{c}\text { Next year } \\
\text { revenue }\end{array}$} & Control vs. Lo NFM & 6649.2 & 0.07 & 0.945 \\
\cline { 2 - 5 } & Control vs. HI NFM & -55633.4 & -0.59 & 0.565 \\
\cline { 2 - 5 } & LO NFM vs. HI NFM & -62282.7 & -0.59 & 0.564 \\
\hline \multirow{2}{*}{$\begin{array}{c}\text { Revenue } \\
\text { growth }\end{array}$} & Control vs. Lo NFM & 0.97 & 0.80 & 0.43 \\
\cline { 2 - 5 } & Control vs. HI NFM & -0.70 & -0.58 & 0.57 \\
\cline { 2 - 5 } & LO NFM vs. HI NFM & -1.67 & -1.24 & 0.23 \\
\hline
\end{tabular}

\section{Second hypothesis testing}

able 4 provides descriptive information about the dependent variables in the three groups in the position of providing non-financial information alone and a high level of knowledge.

Table 4. Descriptive statistics (non-financial information alone and high knowledge)

\begin{tabular}{|c|c|c|c|c|}
\hline Variable & Group & Mean & Standard deviation & N \\
\hline \multirow{3}{*}{$\begin{array}{c}\text { Next year } \\
\text { revenue }\end{array}$} & Control & 852140.00 & 113668.29 & 6 \\
\cline { 2 - 5 } & LO NFM & 845000.00 & - & 1 \\
\cline { 2 - 5 } & HI NFM & 793835.00 & 55199.01 & 4 \\
\cline { 2 - 5 } & Total & 830289.09 & 90631.11 & 11 \\
\cline { 2 - 5 } $\begin{array}{c}\text { Revenue } \\
\text { growth }\end{array}$ & Control & 11.33 & 2.81 & 6 \\
\cline { 2 - 5 } & LO NFM & 9.00 & - & 1 \\
\cline { 2 - 5 } & HI NFM & 10.09 & 3.42 & 4 \\
\hline
\end{tabular}

Descriptive data in Table 4 show that there is not much difference between the groups in the average forecast for the next year and the average estimate of revenue growth for the next 3 to 5 years. Since there is only one observation in the group of LO NFM investors and it is not possible to calculate the standard deviation in this case, in addition to the method of analysis of variance, its nonparametric equivalent, i.e. Kruskal-Wallis test that is based on observations' rating (not their values) is also used to examine the significance of this difference.

Regarding the dispersion of next year's revenue forecast, as shown in Tables 1 and 4, the dispersion of forecasts in the control group is much higher than the other two groups, which promises that the responses are more heterogeneous in the control group. 
The results of the second hypothesis testing for the three groups by oneway ANOVA are presented below:

Based on the results obtained from Table 5, the next year's revenue forecast and the revenue growth forecast for the next 3 to 5 years were estimated to be the same in the three groups at the nominal level of 5 percent. These investors do not differentiate between companies with high performance, low performance, companies that do not provide non-financial information. Using the Kruskal-Wallis test, the next year's revenue forecast and the revenue growth forecast for the next 3 to 5 years were estimated to be the same in the three groups.

Table 5. One-way ANOVA to compare groups (providing non-financial information alone and high knowledge)

\begin{tabular}{|c|c|c|c|c|c|c|}
\hline Variable & $\begin{array}{c}\text { source } \\
\text { variable }\end{array}$ & $\begin{array}{l}\text { Sum of } \\
\text { squares }\end{array}$ & d.f. & $\begin{array}{l}\text { Mean of } \\
\text { squares }\end{array}$ & $\begin{array}{c}\mathbf{F} \\
\text { statistic }\end{array}$ & Sig. \\
\hline \multirow{2}{*}{$\begin{array}{c}\text { Next year } \\
\text { revenue }\end{array}$} & Intergroup & 8396877191 & 2 & 4198393595 & \multirow{2}{*}{0.45} & \multirow{2}{*}{0.650} \\
\hline & Intragroup & 73743197068 & 8 & 9217899634 & & \\
\hline \multirow{2}{*}{$\begin{array}{l}\text { Revenue } \\
\text { growth }\end{array}$} & Intergroup & 20.58 & 2 & 10.29 & \multirow{2}{*}{1.11} & \multirow{2}{*}{0.376} \\
\hline & Intragroup & 74.33 & 8 & 9.29 & & \\
\hline
\end{tabular}

Table 6 shows the results of the contrast test to compare the groups in pairs. As can be observed, all significance values are greater than 0.05; therefore, there is no significant difference between the groups in pair in predicting the next year revenue and revenue growth in the next 3 to 5 years.

Table 6. Contrasts test (non-financial information alone and high knowledge)

\begin{tabular}{|c|c|c|c|c|}
\hline Variable & Contrasts & Value of contrasts & T statistic & Sig. \\
\hline \multirow{2}{*}{$\begin{array}{c}\text { Next year } \\
\text { revenue }\end{array}$} & Control vs. Lo NFM & 7140.0 & 0.07 & 0.947 \\
\cline { 2 - 5 } & Control vs. HI NFM & 58305.0 & 0.94 & 0.374 \\
\cline { 2 - 5 } & LO NFM vs. HI NFM & 51165.0 & 0.48 & 0.646 \\
\hline \multirow{2}{*}{$\begin{array}{c}\text { Revenue } \\
\text { growth }\end{array}$} & Control vs. Lo NFM & 2.33 & 0.71 & 0.499 \\
\cline { 2 - 5 } & Control vs. HI NFM & 2.83 & 1.44 & 0.188 \\
\cline { 2 - 5 } & LO NFM vs. HI NFM & 0.50 & 0.15 & 0.887 \\
\hline
\end{tabular}

\section{Third hypothesis testing}

Table 7 provides descriptive information about the dependent variables in the three groups in the position of providing non-financial information and receiving causal links for investors with a low level of knowledge. 
Table 7. Descriptive statistics (non-financial information with causal links for investors with low knowledge in million Rials)

\begin{tabular}{|c|c|c|c|c|c|c|c|}
\hline \multirow{3}{*}{ Variable } & \multirow{3}{*}{ Group } & \multicolumn{6}{|c|}{ Receiving causal links } \\
\hline & & \multicolumn{3}{|c|}{ No } & \multicolumn{3}{|c|}{ Yes } \\
\hline & & Mean & $\begin{array}{l}\text { Standard } \\
\text { deviation }\end{array}$ & $\mathbf{N}$ & Mean & $\begin{array}{l}\text { Standard } \\
\text { deviation }\end{array}$ & $\mathbf{N}$ \\
\hline \multirow{4}{*}{$\begin{array}{l}\text { Next } \\
\text { year } \\
\text { revenue }\end{array}$} & Control & 783310.40 & 226465.49 & 10 & - & - & - \\
\hline & $\begin{array}{l}\text { LO } \\
\text { NFM }\end{array}$ & 776661.17 & 121280.58 & 6 & 923759.00 & - & 1 \\
\hline & $\begin{array}{l}\mathrm{HI} \\
\text { NFM }\end{array}$ & 838943.83 & 136932.68 & 6 & 844169.16 & 65981.54 & 9 \\
\hline & Total & 796669.73 & 176798.87 & 22 & 852128.14 & 67106.55 & 10 \\
\hline \multirow{4}{*}{$\begin{array}{l}\text { Revenue } \\
\text { growth }\end{array}$} & Control & 10.30 & 2.21 & 10 & - & - & - \\
\hline & $\begin{array}{l}\text { LO } \\
\text { NFM }\end{array}$ & 9.33 & 2.73 & 6 & 5.00 & - & 1 \\
\hline & $\begin{array}{l}\mathrm{HI} \\
\text { NFM }\end{array}$ & 11.00 & 2.10 & 6 & 10.67 & 2.78 & 9 \\
\hline & Total & 10.23 & 2.31 & 22 & 10.10 & 3.18 & 10 \\
\hline
\end{tabular}

Descriptive information in Table 7 shows that the mean revenue forecast for the next year for people who have not received information related to complementary causal links is 796669.73 million Rials and for people who have received information related to complementary causal links is 852128.14 million Rials. In general, not much difference is observed. The average level of assessment of income growth in the next 3 to 5 years was reported to be 10.23 for those who did not receive information on causal links and 10.10 for those who received information related to causal links, showing that there is not much difference.

Below are the results of the third hypothesis testing. In testing this hypothesis, two-way ANOVA was used to investigate the effect of nonfinancial intangible information (NFM) and complementary causal link information (Link) on the prediction of dependent variables.

Based on the results from table 8, providing non-financial information and receiving complementary causal links does affect next year's revenue forecast and revenue growth forecast of the next 3 to 5 years at a nominal level of 5 percent. The provision of non-financial intangible information does not affect next year's revenue forecast and revenue growth forecast in the next 3 to 5 years at a nominal level of 5 percent. Also, receiving complementary causal links does not affect next year's revenue forecast and revenue growth forecast in the next 3 to 5 years at a nominal level of 5 percent. 
Table 8. two-way ANOVA (non-financial intangible information and causal links for investors with low knowledge)

\begin{tabular}{|c|c|c|c|c|c|c|}
\hline Variable & $\begin{array}{c}\text { source } \\
\text { variable }\end{array}$ & Sum of squares & d.f. & Mean of squares & $\begin{array}{c}\text { F } \\
\text { statistic }\end{array}$ & Sig. \\
\hline \multirow{4}{*}{$\begin{array}{c}\text { Next year } \\
\text { revenue }\end{array}$} & Link & 16063161036.0 & 1 & 16063161036.0 & 0.64 & 0.430 \\
\cline { 2 - 7 } & NFM & 3479352535.0 & 2 & 1739676268.0 & 0.07 & 0.933 \\
\cline { 2 - 8 } & $\begin{array}{c}\text { Link } \times \\
\text { NFM }\end{array}$ & 13934637283.0 & 1 & 13934637283.0 & 0.56 & 0.462 \\
\cline { 2 - 8 } & Error & $11+\mathrm{e} 6.76$ & 27 & & & \\
\hline \multirow{4}{*}{$\begin{array}{c}\text { Revenue } \\
\text { growth }\end{array}$} & Link & 15.08 & 1 & 15.08 & 2.46 & 0.128 \\
\cline { 2 - 8 } & NFM & 37.33 & 2 & 18.66 & 3.05 & 0.064 \\
\cline { 2 - 8 } & LFM $\times$ & 11.08 & 1 & 11.08 & 1.81 & 0.190 \\
\cline { 2 - 8 } & error & 165.43 & 27 & 6.13 & & \\
\hline
\end{tabular}

\section{Fourth hypothesis testing}

Table 9 provides descriptive information about the dependent variables in the three groups in the position of providing non-financial information and receiving causal links for investors with a high level of knowledge.

Table 9. Descriptive statistics (non-financial information with causal links for investors with high knowledge in million Rials)

\begin{tabular}{|c|c|c|c|c|c|c|c|}
\hline \multirow{3}{*}{ Variable } & \multirow{3}{*}{ Group } & \multicolumn{6}{|c|}{ Receiving causal links } \\
\hline & & \multicolumn{3}{|c|}{ No } & \multicolumn{3}{|c|}{ Yes } \\
\hline & & Mean & $\begin{array}{l}\text { Standard } \\
\text { deviation }\end{array}$ & $\mathbf{N}$ & Mean & $\begin{array}{l}\text { Standard } \\
\text { deviation }\end{array}$ & $\mathbf{N}$ \\
\hline \multirow{4}{*}{$\begin{array}{c}\text { Next } \\
\text { year } \\
\text { revenue }\end{array}$} & Control & 852140.00 & 113668.29 & 6 & - & - & - \\
\hline & $\begin{array}{c}\text { LO } \\
\text { NFM }\end{array}$ & 845000.00 & - & 1 & 800000.00 & - & 1 \\
\hline & $\begin{array}{c}\text { HI } \\
\text { NFM }\end{array}$ & 793835.00 & 55199.01 & 4 & 815151.33 & 91162.75 & 6 \\
\hline & Total & 830289.09 & 90631.11 & 11 & 812986.86 & 83416.63 & 7 \\
\hline \multirow{4}{*}{$\begin{array}{l}\text { Revenue } \\
\text { growth }\end{array}$} & Control & 11.33 & 2.81 & 6 & - & - & - \\
\hline & $\begin{array}{c}\text { LO } \\
\text { NFM }\end{array}$ & 9.00 & - & 1 & 7.00 & - & 1 \\
\hline & $\begin{array}{c}\text { HI } \\
\text { NFM }\end{array}$ & 8.50 & 3.42 & 4 & 10.17 & 0.75 & 6 \\
\hline & Total & 10.09 & 3.08 & 11 & 9.71 & 1.38 & 7 \\
\hline
\end{tabular}


Descriptive information in Table 9 shows that the mean revenue forecast for the next year for people who have not received information related to complementary causal links is 830289.09 million Rials and for people who have received information related to complementary causal links is 812986.86 million Rials. In general, not much difference is observed. The average level of assessment of income growth in the next 3 to 5 years was reported to be 10.09 for those who did not receive information on causal links and 9.71 for those who received information related to causal links, showing that there is not much difference.

Below are the results of the fourth hypothesis testing. In testing this hypothesis, two-way ANOVA was used to investigate the effect of nonfinancial intangible information (NFM) and complementary causal link information (Link) on the prediction of dependent variables.

Based on the results from table 10, providing non-financial information and receiving complementary causal links does affect next year's revenue forecast and revenue growth forecast of the next 3 to 5 years at a nominal level of 5 percent. The provision of non-financial intangible information does not affect next year's revenue forecast and revenue growth forecast in the next 3 to 5 years at a nominal level of 5 percent. Also, receiving complementary causal links does not affect next year's revenue forecast and revenue growth forecast in the next 3 to 5 years at a nominal level of 5 percent.

Table 10. two-way ANOVA (non-financial intangible information and causal links for investors with high knowledge)

\begin{tabular}{|l|l|c|c|c|c|c|}
\hline \multirow{2}{*}{ Variable } & $\begin{array}{c}\text { Source } \\
\text { variable }\end{array}$ & $\begin{array}{c}\text { Sum of } \\
\text { squares }\end{array}$ & d.f. & Mean of squares & F statistic & Sig. \\
\hline \multirow{3}{*}{$\begin{array}{l}\text { Next } \\
\text { year } \\
\text { revenue }\end{array}$} & Link & 232103200.0 & 1 & 232103200.0 & 0.03 & 0.874 \\
\cline { 2 - 8 } & NFM & 4023143109.0 & 2 & 2011571555.0 & 0.23 & 0.800 \\
\cline { 2 - 8 } & Link $\times$ & 1819802510.0 & 1 & 1819802510.0 & 0.21 & 0.658 \\
\cline { 2 - 8 } & EFM & $1.15 e+11$ & 13 & & 0.01 & 0.931 \\
\hline \multirow{3}{*}{$\begin{array}{l}\text { Revenue } \\
\text { growth }\end{array}$} & Link & 0.05 & 1 & 0.05 & 1.19 & 0.335 \\
\cline { 2 - 8 } & LFM & 14.12 & 2 & 7.06 & 0.94 & 0.351 \\
\cline { 2 - 8 } & NFM & 5.56 & 1 & 5.56 & & \\
\hline
\end{tabular}




\section{Fifth hypothesis testing}

For testing the fifth hypothesis, participants were asked questions about the number of projects in the development line, the time of completion of the new project, the level of knowledge about the R\&D process strategy, and the status of receiving information about the $R \& D$ process strategy.

Table 11. Descriptive statistics (receiving complementary causal links)

\begin{tabular}{|c|c|c|c|c|c|c|}
\hline \multirow{2}{*}{ Variable } & \multicolumn{6}{|c|}{ Neceiving causal links } \\
\cline { 2 - 7 } & \multicolumn{4}{|c|}{ No } & \multicolumn{3}{c|}{ Yes } \\
\cline { 2 - 7 } & Mean & $\begin{array}{c}\text { Standard } \\
\text { deviation }\end{array}$ & $\mathbf{N}$ & Mean & $\begin{array}{c}\text { Standard } \\
\text { deviation }\end{array}$ & $\mathbf{N}$ \\
\hline $\begin{array}{c}\text { Number of projects in the } \\
\text { development line }\end{array}$ & 7.09 & 3.84 & 33 & 11.00 & 0.00 & 17 \\
\hline $\begin{array}{c}\text { Time of the completion of the } \\
\text { new project }\end{array}$ & 3.33 & 2.37 & 33 & 1.35 & 0.70 & 17 \\
\hline $\begin{array}{c}\text { level of knowledge about the } \\
\text { R\&D process strategy }\end{array}$ & 1.58 & 1.64 & 33 & 3.65 & 2.12 & 17 \\
\hline
\end{tabular}

The result of the assumption of homogeneity of error variances can be seen in Table 12. As can be seen, for the number of projects in the development line and the completion time of the new project, the homogeneity test is not approved at the nominal level of 5 percent. Therefore, the independent t-test is used with the assumption of inequality of variance to investigate the effect of causal links. For the level of knowledge about the strategy of the R\&D process, the homogeneity test is approved at a nominal level of 5 percent.

Table 12. Levene's test for homogeneity of error variances in independent t-test

\begin{tabular}{|l|c|c|c|}
\hline \multicolumn{1}{|c|}{ Variable } & $\begin{array}{c}\text { Levene's } \\
\text { statistics }\end{array}$ & d.f. & Sig. \\
\hline Number of projects in the development line & 118.41 & 48 and 1 & 0.000 \\
\hline Time of the completion of the new project & 12.03 & 48 and 1 & 0.001 \\
\hline $\begin{array}{l}\text { level of knowledge about the R\&D process } \\
\text { strategy }\end{array}$ & 1.70 & 48 and 1 & 0.199 \\
\hline
\end{tabular}

Based on the results obtained from Table 13, receiving complementary causal links has an effect on the number of projects in the development line, the time of completion of a new project and the level of knowledge about the $\mathrm{R} \& \mathrm{D}$ process strategy at a nominal level of 5 percent. 
Table 13. independent t-test to examine the effect of complementary causal links

\begin{tabular}{|l|c|c|c|c|}
\hline \multicolumn{1}{|c|}{ Variable } & $\begin{array}{c}\text { Mean } \\
\text { difference }\end{array}$ & d.f. & T statistic & Sig. \\
\hline $\begin{array}{l}\text { Number of projects in the } \\
\text { development line }\end{array}$ & -3.91 & 32.00 & -5.84 & 0.000 \\
\hline $\begin{array}{l}\text { Time of the completion of a new } \\
\text { project }\end{array}$ & 1.98 & 41.44 & 4.44 & 0.000 \\
\hline $\begin{array}{l}\text { level of knowledge about the R\&D } \\
\text { process strategy }\end{array}$ & -2.07 & 48.00 & -3.83 & 0.000 \\
\hline
\end{tabular}

In table 14, the descriptive information comprises the frequency and percentage of received information about the $R \& D$ process strategy. As can be observed, there is a significant difference between the two groups $(p=0.016<$ $0.05)$.

Table 14. The frequency of the state of receiving information about the R\&D strategy

\begin{tabular}{|c|c|c|}
\hline State of receiving information about the R\&D & \multicolumn{2}{|c|}{ Receiving causal links } \\
process strategy & No & Yes \\
\hline Yes & $8(24.2 \%)$ & $10(58.8 \%)$ \\
\hline No & $25(75.8 \%)$ & $7(41.2 \%)$ \\
\hline Total & $33(100.0 \%)$ & $17(100.0 \%)$ \\
\hline
\end{tabular}

\section{Conclusion and suggestions}

In today's world of knowledge, where intangible assets are of particular importance, due to the intangible nature of these assets and the limited standards for measuring and disclosing them, users seem to pay less attention to this kind of information in decision-making. Therefore, the present study sought to provide an appropriate method for the disclosure of intangible information. To this end, with an emphasis on non-financial information that is a consequence of intangible investment, two sets of hypotheses were proposed to examine the effect of complementary causal links (as a tool to help decisionmaking) along with disclosing non-financial intangible information on investors' judgement. The results of hypotheses testing were as follows:

The findings confirmed the first hypothesis. Therefore, If non-financial intangible information is disclosed alone, it will not be included in the performance judgment by investors with low knowledge of the industry. These investors will not differentiate between companies with above-average nonfinancial performance, below-average non-financial performance, and non- 
disclosing companies (control/baseline condition).

The second hypothesis is rejected. Therefore, if non-financial intangible information is disclosed alone, it is not included in the performance judgment by investors with high knowledge of the industry. These investors will not differentiate between companies with above-average non-financial performance, below-average non-financial performance, and non-disclosing companies (control/baseline condition).

Contrary to expectations, the research findings do not confirm the third hypothesis. Thus, if the discussion of complementary causal links is provided with non-financial intangible information (considering the interaction between providing non-financial intangible information and receiving complementary causal links), performance judgment by investors with low knowledge of the industry will not be affected.

Based on the research findings, the fourth hypothesis is confirmed. Thus, if the discussion of complementary causal links is provided with non-financial intangible information, performance judgment by investors with high knowledge of the industry will not be affected.

The results showed that the fifth hypothesis is confirmed. Therefore, recall of performance on non-financial criteria will be higher for investors who receive the discussion of the causal links than other investors. According to the findings, in general, investors who receive a discussion of causal links are more reminiscent of non-financial information than investors who do not. It is worth pondering why, contrary to expectations, the simultaneous presentation of nonfinancial intangible information and complementary causal links does not further influence the judgment of investors with low knowledge of the industry (rejection of the third hypothesis).

The results of the present study are not in accordance with similar studies in some cases (such as Buzinskiene, 2017; Arvidsson, 2011; Yen, 2004). The reasons for the difference may be due to:

(1) Despite investors' awareness of intangible information, their lack of attention to non-financial intangible information, failure to use tools to help decision-making (discussion of complementary causal links) or incorrect interpretation and processing of this information have caused this issue. Investors who are unaware of the value of intangible information can intensify this situation. (2) Investors may have placed more emphasis on their core 
beliefs, even in the face of new information, because people follow the anchors and rules of the mind. (3) In addition to financial information, investors in Iran may rely on other factors, such as economic conditions prevailing in the country, existing laws regarding a particular industry, and existing rumors, in order to make decisions. (4) How individuals acquire knowledge and the type of educational and training structure may be important in decision-making and judgment, leading to such a condition. (5) Limitations and gaps arising from current accounting standards regarding intangible information may have led to this.

Therefore, based on the research findings and considering the importance of non-financial intangible information in today's knowledge-based economy, investors are suggested to pay more attention to intangible information, especially non-financial information that is the output of intangible activities and consider this information in their decision-making and judgement in the process of valuing companies. Managers of business units are proposed to pay more attention and be sensitive to the disclosure of non-financial intangible information. Because increasing disclosure transparency helps managers to have more effective disclosure and helps them achieve their goal of better information transfer. On the other hand, the standards development organization and audit organization, as the custodians of the development, are proposed to consider executive strategies to monitor the registration and disclosure of non-financial intangible information. The curriculum development committee is recommended to include courses on intangible assets and related non-financial information in the curricula of the postgraduate students of accounting.

In the present study, knowledge and tools facilitating decision-making were used as personality factors affecting judgment and decision-making. Future researchers are proposed to carry out similar research using other factors, such as environmental factors affecting decision making, including group decision making rather than individual decision making. It is also recommended to conduct similar research in other specific industries that have high intangible assets, and instead of using R\&D information, use other intangible information, such as human resource training costs as future research. This research was done by qualitative method; to reduce prearbitration and personal interpretations and better understand the context and situation, researchers are suggested to use hybrid research methods in future research.

The main limitation in doing this research was the preparation and 
extraction of intangible information, especially R\&D costs, from complementary notes. Some non-financial information of the company is not easily available to the public, which may be for competitive reasons. It should be noted that Iranian pharmaceutical companies are forced to receive facilities due to the long period of receivables, which leads to considerable growth in their financial costs. Part of the low net profit growth can be due to increased financial costs. Also, since the data collection tool was a questionnaire, there were limitations to the questionnaire, including the possibility of not returning the questionnaire, the probability of not understanding the concepts and content of the questionnaire, ambiguity for the respondents, and so on.

Funding: This research received no external funding.

\section{References}

Ajzen, I. (1977). "Intuitive Theories of Events and the Effects of BaseRate Information on Prediction". Journal of Personality and Social Psychology, 35: 303-314.

Arefmanesh, Z., \& Rahmani, A. (2015). "modeling of intangible assets in accepted companies in Tehran stock exchange". journal of management accounting 8(26): 81-112.

Arefmanesh, Z., Rahmani, A., Hejazi, R., \& Amirshahi, M. (2016). "Investigating the value relevance of intangible assets in future earnings and future cash flow". journal of knowledge of financial

accounting, 3(1): 1-20.

Arvidsson, S. (2011). "Disclosure of Non-financial Information in the Annual Report". Journal of Intellectual Capital, 12(2): 277-300.

Bini, L., Simoni, L., Dainelli, F., \& Giunta, F. (2018). "Business model and non-financial key performance indicator disclosure". Journal of Business Models, 6(2): 5-9.

Buzinskiene, R. (2017). Determination of the Value of Intangible Assets in the Companies of Lithuania. Journal of Economics and Culture, 14(2): 5568.

Cardinaels, E. (2008). "The interplay between cost accounting knowledge and presentation formats in cost-based decision-making". 
Accounting, Organizations and Society, 33: 582-602.

Dan L. (2007). "Estimating activity costs: How the provision of accurate historical activity data from a biased cost system can improve individuals' cost estimation accuracy". Behavioral Research in Accounting, 19: 133-159.

Daniel, Z., \& Anis, M. (2011). "The accounting treatment of intangibles - a critical review of the literature". Accounting Forum, 35: 262-274. Developing accounting standards committee, audit organization (2008). Iranian accounting standards, standards number $3 \& 17$.

Dyczkowska, J. (2016). "Determinants and Quality of R\&D Disclosures in Annual Reports of Biotechnological Companies". Wrocla University of Economics. Online Retrieved from https://researchgate.net.

Eccles, R.G., Herz, R.H., Keegan, E.M., \& Phillips, D.M.H. (2001). “The Value Reporting: Moving Beyond the Earnings Game”. New York: John Wiley \& Sons, New York, NY.

Einhorn, H.J., \& Hogarth, R.M. (1986). "Judging probable cause". Psychological Bulletin, 99: 3-19.

Elliot W.B., Hoge F.D., Kennedy J.J., \& Ponk M. (2007). “Are M.B.A. students a good proxy for nonprofessional investors?". The Accounting Review, 82(1): 139-168.

Fadur, C., \& Mironius, M. (2013). "Study on the perception of accounting professionals concerning intangible assets and intangible capital". Theoretical and Applied Economics, xx (4): 77-98. Financial Accounting Standards Board - FASB NN. (2001a). "Getting a grip on intangible assetswhat they are, why they matter, and who should be managing them in your organization". Harvard Management Update, 6(2): 6-8.

Ghanbari, M., Fathallahi, kh., Mozafari, S., \& Ghorbanzadeh, M. (2017). "review the role of non-financial performance measures in disclosure in financial reporting". new research in accounting and management, 21(10): 165-174.

Hales, J., Xi (Jason) K., \& Venkataraman S. (2011). "Who believes the hype? An experimental examination of how language affects investor judgments". Journal of Accounting Research, 40(1): 223-255. Heitger,

Hendricksen, E. F. (1982). Accounting Theory, Richard D, Irwin Homewood, Chapter 5: 102-15. 
Khani, A., Sadeghi, M., \& Mohammadi Holeh Soe, M. (2014). "effect of research and development costs on the stock return of active pharmaceutical companies in Tehran stock exchange". Quarterly financial accounting, 6(21): $153-174$

Lev, B. (1999). "R\&D and Capital Markets". Journal of Applied Corporate Finance, 11: 21-35.

Mahmudi, M., Hadian, S. A., \& Fallah Abed, T. (2015). "impact level of voluntary disclosure quality of financial and non-financial measures on earnings forecast". journal of financial management guideline, 3(10): 105-128.

Mashaykhi, B., Beyrami, H., \& Beyrami, H. (2014). "determining the value of intangible assets using artificial neural network". journal of empirical accounting research, 4(14): 223-238.

Mazaheri, A. (2014). "accounting methods of intangible assets and challenges ahead". Journal of accounting and auditing studies, 3(9): 113-125.

Mehrpoyafar, N. (2016). "investigating the effect of disclosure of research and development information on the cost of capital study of active companies in the chemical, pharmaceutical and food industries accepted in Tehran stock exchange" Master's Thesis, The Mazandaran University, Retrieved from Iran dock.

Parvai, A., \& Kordestani, Gh. (2018). "behavioral explanation of management decisions in the field of investment in intangible assets: reward hypothesis testing based on the experimental approach". review of accounting and auditing, 25(4): 479-496.

Rahnama Roudposhti, F., Nikomaram, H., \& Nonahal Nahr, A. A. (2012). "Evaluation of the impact of judgment and cognitive approaches in accounting explanation reports". Review of accounting and auditing, 19(2): 4772 .

Sharma, K., \& Kaur, M. (2019). "Intangible assets: reporting practices and hidden value measurement". The research journal of social sciences, 10(1): 102-118.

Swanson, Z. (2018).” Internal intangible asset effect on firm valuation. University of Central Oklahoma, SSRN Database", Available at: http: //dx.doi.org /10 .2139/ssrn.3134117.

Tversky, A., \& Kahneman, D. (1980). "Causal Schemas in Judgments under Uncertainty". In M. Fishbein (Ed.). Progress in Social Psychology, New 
York, Lawrence Earlbaum Associates.

Upton, W.S., Jr. (2001). "Special Report: Business and Financial Reporting, Challenges from the New Economy". Stamford, CT: FASB.

Valizadeh Larijani, A., \& Hadidifard, A. (2016). "The relationship between financial and accounting factors with Profit dividend ratio in different stages of business life". Journal of the stock exchange, 9(36): 75-96.

Winchel, J. (2008). "When do negative arguments increase the credibility of favorable analyst reports?" The University of Texas of Austin.

Yari, F. (2018). "Independent trust of non-financial information: securing trust”. Journal of auditor, 96: 26-28.

Yen, A. C. C. (2004). "Effects on investor judgements from expanded disclosures of nonfinancial intangibles information". The University of TexasAustin. Online Retrieved from https://repositories.lib.utexas.edu.

Bibliographic information of this paper for citing:

Mosallanezhad, Tahereh; Khajavi, Shokrallah; Gholami, Abdolkhalegh \& Valipour, Hashem (2021). Investigating the Effects of Disclosure of NonFinancial Intangible Information on Investors' Judgment about Future Financial Performance of the Company. Iranian Journal of Finance, 5(2), 2145.

Copyright @ 2021, Tahereh Mosallanezhad, Shokrallah Khajavi, Abdolkhalegh Gholami and Hashem Valipour 